\title{
2. Aim and scope of the work
}

\author{
Jolanta Adamczyk, Stanisław Krysiak, Anna Majchrowska, Elżbieta Papińska
}

The aim of the work was to:

1. Recognise the location of abandoned lands in the study areas.

2. Identify the landscape ecological structure by delimitation of geocomplexes (morpholithohydrotopes) in order to describe geomorphology, lithology, hydrology and soils of the study areas.

3. Make an inventory of vascular plant species and macromycetes of selected abandoned lands.

4. Provide a description of vegetation that grows on the analysed abandoned lands.

5. Evaluate the relationship between the location of abandoned lands and the abiotic features of the natural environment.

6. Determine the relationship between the abandoned land vegetation and the abiotic features of the habitat.

7. Evaluate the ecological role of abandoned lands in the agricultural landscape of the Łódź Voivodeship, taking into consideration their abiotic conditions and specific features of vegetation and macromycetes.
The research was conducted in the 10-kilometre wide buffer zones which surround all landscape parks in the Łódź Voivodeship (Fig. 2.1). The research included an area of $7205 \mathrm{~km}^{2}$. In the case of the Łódź Hills Landscape Park, the Warta-Widawka Interfluve Landscape Park and the Sulejów Landscape Park, the surrounding $10-\mathrm{km}$ zones are located within the borders of the voivodeship. The fragments of zones surrounding the Bolimów Landscape Park, Przedbórz Landscape Park, Spała Landscape Park and Załęcze Landscape Park which lie in the neighbouring voivodeships were excluded from the research.

The geocomplexes were delimited both in the areas of landscape parks and in their buffer zones. It enabled to present the relationships of landscape ecological structure of the surroundings of landscape parks and the parks themselves, and made the whole landscape ecological structure visible, in particular the continuous character of geocomplexes of river valleys (for example of the Pilica, the Warta and the Rawka river valleys). 


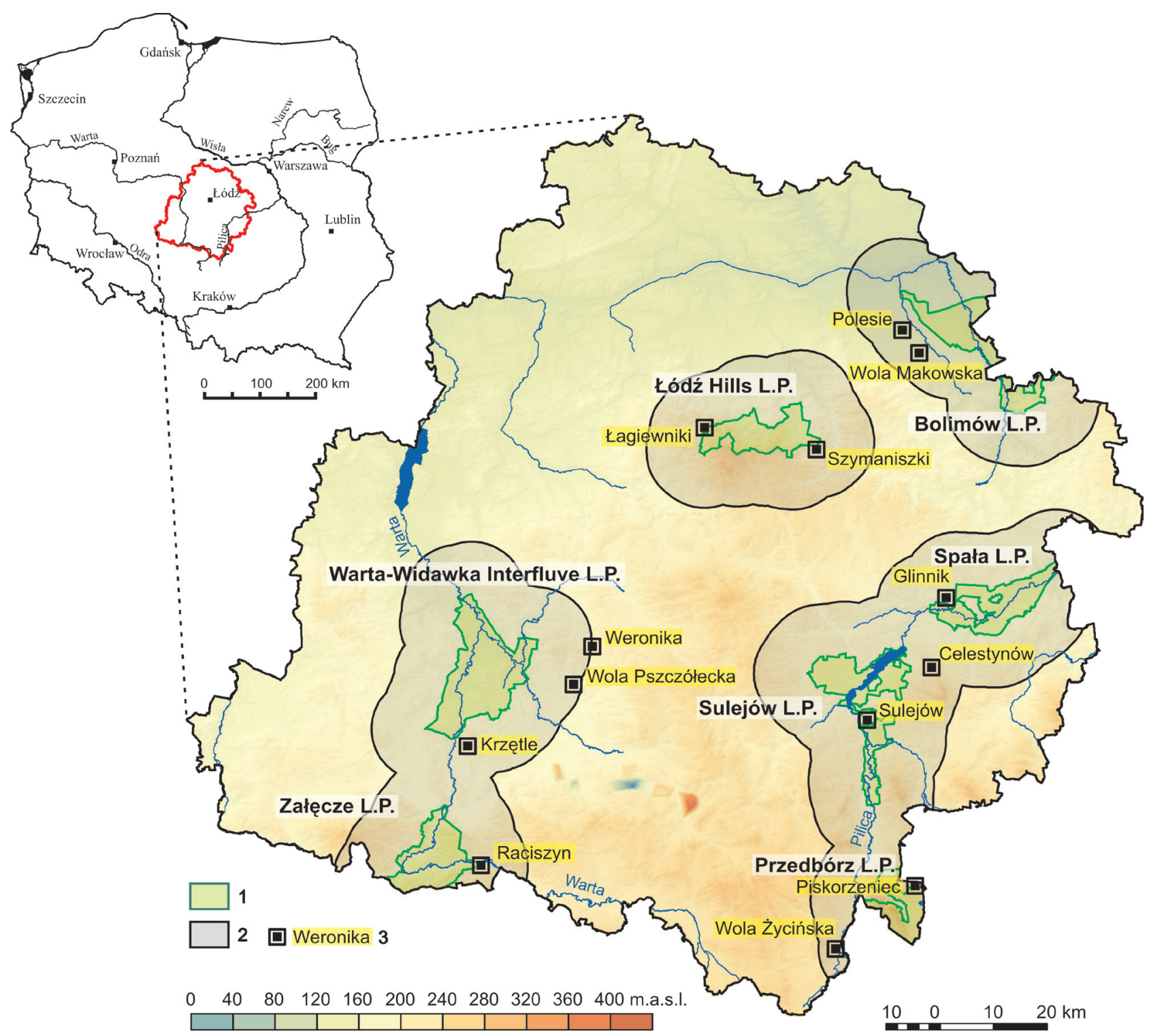

Fig. 2.1. The study area, encompassing the $10-\mathrm{km}$ wide buffer zones around the seven landscape parks of the Łódź Voivodeship, and the location of study plot groups

1 - landscape park area; 2 - 10-km wide buffer zone around a landscape park; 3 - study plot group

Source: own elaboration based on digital elevation model with grid interval of at least $100 \mathrm{~m}$ and other data made available by CODGiK (www.codgik.gov.pl) 